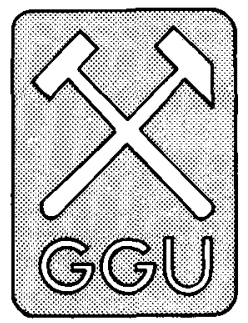

\title{
An overview of Greenland's mineral exploration potential
}

\author{
Hans K. Schфnwandt and Peter R. Dawes
}

Part of the 1992 promotion campaign to North America and Europe, to provide geoscientific data to exploration and mining audiences was an oral presentation of Greenland's exploration potential. The background and aims of the campaign are outlined elsewhere in this report by Dawes $e t$ al. The oral presentation focused on the main geological provinces of Greenland and their mineral occurrences (excluding fossil fuels), but geographical and logistic subjects were also broached. This paper gives a summary of the geological part of the presentation and concentrates on metalliferous potential.

For conciseness no references on specific mineral occurrences are given in the text. A full account of the mineral potential of Greenland with an extensive bibliography is planned.

\section{Geological framework and setting}

Greenland is the largest island in the world with an area of over 2 million square kilometres. The Inland Ice, up to $3 \mathrm{~km}$ thick, covers the central part of the island, leaving an ice-free fringe $\left(385,000 \mathrm{~km}^{2}\right)$ that is roughly equivalent in area to many European countries, for example Norway or Finland. This outer rim, which is as much as $250 \mathrm{~km}$ wide, provides rock exposures among the best in the world.

Geologically Greenland is part of the North American continent and there is good correlation of the major rock divisions of western Greenland with those of neighbouring Canada (Fig. 1). Greenland preserves an almost complete geological column with rocks ranging in age from the earliest Precambrian (3800 Ma) to Holocene. Precambrian crystalline rocks predominate and make up a central stable craton. Proterozoic-Phanerozoic sedimentary and volcanic strata preserved around the margin of this craton form both undeformed platform cover, faulted and weakly deformed outcrops and folded and metamorphosed successions now welded into orogenic belts (Fig. 1). Tertiary magmatic rocks occur in eastern and western Greenland facing the oceanic provinces of, respectively, the North Atlantic and Labrador Sea/Baffin Bay while Cretaceous peralkaline volcanicity is associated with the northern margin of Greenland facing the Arctic Ocean (Fig. 1).

The short description above covers in broad terms Greenland's principal geological provinces used for the descriptive framework of this paper. These are:

\section{Precambrian crystalline shield \\ Late Proterozoic intracratonic deposits \\ Palaeozoic orogenic belts \\ North Greenland fold belt (Innuitian) \\ East Greenland fold belt (Caledonian) \\ Late Palaeozoic - Mesozoic sediments \\ Late Phanerozoic magmatism}

\section{Potential, mining and exploration}

Significant occurrences of a broad range of metallic and industrial minerals are present in rocks of Precambrian to Tertiary age; Holocene placer deposits are also known. All five provinces outlined above have revealed economic resources (Fig. 2), some of which have been exploited.

The three most notable mining activities have been the cryolite extraction in the period 1858 to 1987 from a late Proterozoic intrusion at Ivittuut in South-West Greenland, the lead-zinc-silver production at Maarmorilik (Black Angel), central West Greenland (1973 to 1990) from an early Proterozoic deformed marble, and the lead-zinc production from quartz veins at Blyklippen in central East Greenland (1956 to 1963). The closure of the Black Angel mine leaves Greenland at the present time without an active mining operation.

In 1992 a total of 37 mineral exploration licences were in force. Drilling has been undertaken on a number of projects and most of the cores are now stored in GGU's core library in Copenhagen. Another GGU facility the Greenland Mineralisation Data Bank (GREENMIN) - provides information on mineral occurrences in a systematic and accessible form for direct use by industry. 


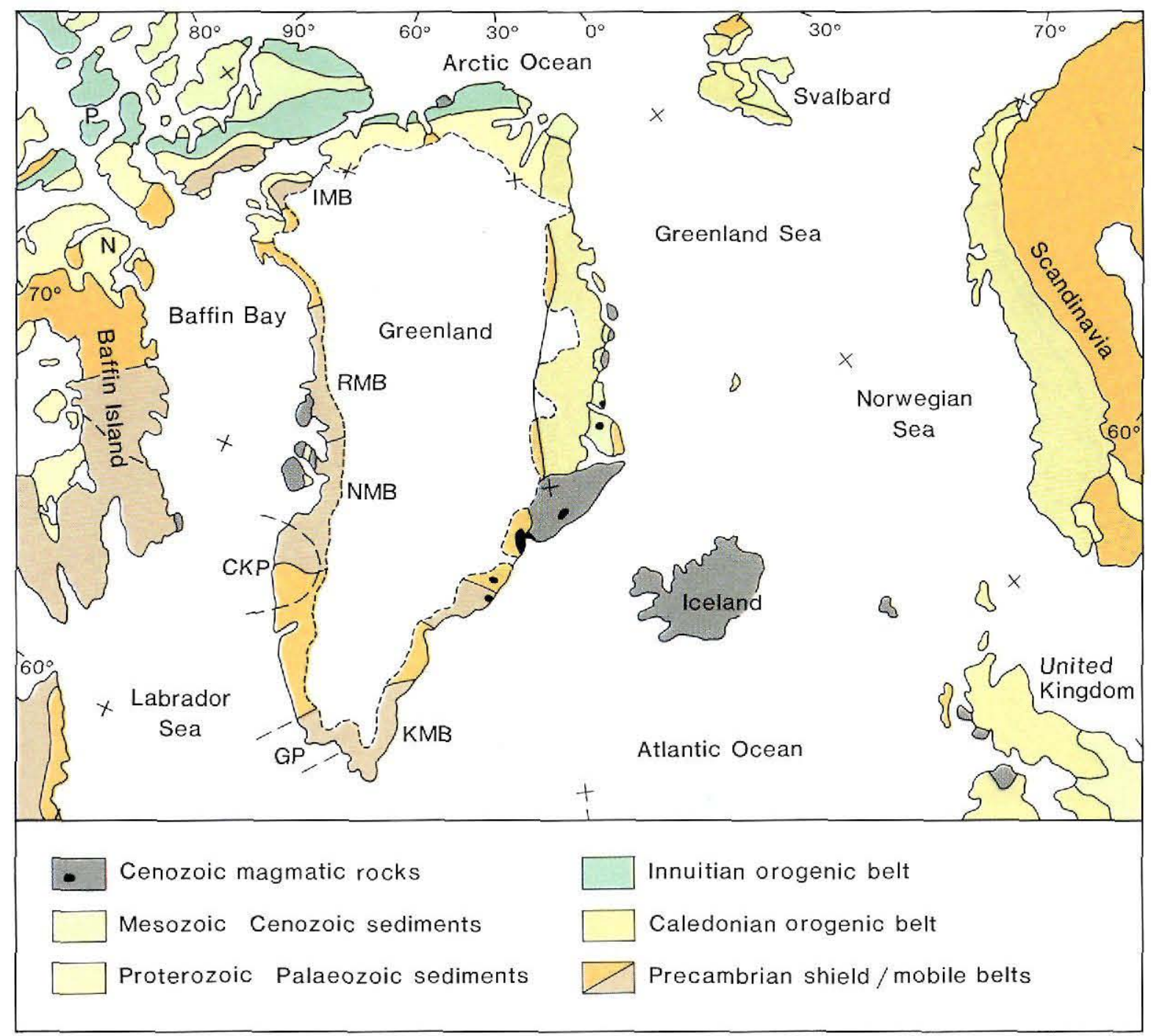

Fig. 1. Greenland's location in the North Atlantic region, with main geological divisions. $\mathrm{N}=\mathrm{Nanisivik}$ mine; $\mathrm{P}=\mathrm{Polaris}$ mine; $\mathrm{CKP}=$ central part of carbonatite/kimberlite province; GP $=$ Gardar province; $\mathrm{IMB}=$ Ingleficld Land mobile belt; $\mathrm{KMB}=$ Ketilidian mobile belt; $\mathrm{NMB}=$ Nagssugtoqidian mobile belt; $\mathrm{RMB}=$ Rinkain mobile belt.

\section{Precambrian crystalline shield}

The shield makes up about $70 \%$ of the exposed bedrock of Greenland, forming large outcrops in all regions except the far north (Fig. 1). It is composed of both Archaean and early Proterozoic crustal material. These two ages of rock form discrete terranes but in many regions they are intimately associated and the detailed spatial relationship of Archaean and younger crust has not been determined. Large areas of the Archacan have been reworked in the Proterozoic, while in eastern Greenland (within the Caledonian fold belt, see later), both Archaean and Proterozoic complexes have been overprinted during the Palacozoic.

\section{Archaean and reworked Archaean terrane}

Rocks of these ages occur throughout western and eastern Greenland from $61^{\circ} \mathrm{N}$ (Ivittuut) to the northern exposures of the shield at $81^{\circ} \mathrm{N}$ (Victoria Fjord). The largest continuous Archaean mass, unaffected by Proterozoic reactivation, is the southern block (Fig. 1) which was mainly formed between $3000-2000 \mathrm{Ma}$ ago. Within 
this block is a unit of early Archaean gneisses (Amitsôq) and a supracrustal belt (Isua) that formed 3800-3600 $\mathrm{Ma}$ ago. The reworked Archaean terrane of western Greenland includes the Nagssugtoqidian mobile belt and the crystalline basement rocks of the Rinkian mobile belt (Fig. 1).

The Archaean and reworked Archaean terrane is dominated by multiphase orthogneisses and granitoid rocks. In the southern Archaean block in West Greenland gabbro-anorthositic bodies and supracrustal rocks each make up about $10 \%$ of the rock suite. Greenstones often occur as enclaves of varying dimension but more coherent belts with dimensions of tens of kilometres also exist.

Most exploration activity has been concentrated on the greenstone and supracrustal belts and on the chromite potential of the Fiskenæsset anorthosite complex. Several supracrustal belts (e.g. Tartoq Group, $62^{\circ} \mathrm{N}$; Atâ supracrustals, $71^{\circ} \mathrm{N}$ ) show good potential for gold and base metal mineralisations and the Isua supracrustals $\left(64^{\circ} \mathrm{N}\right)$ host a major iron formation. Other ironstone occurrences are in the Nuussuaq area $\left(70^{\circ} \mathrm{N}\right)$ and in the Melville Bugt - Thule district $\left(75-76^{\circ} \mathrm{N}\right.$; Figs 2 \& 3).

The Archaean and reworked Archaean rocks have not yet yielded mineable deposits, although the terrane holds a potential for a suite of elements. The principal occurrences so far found are:

\section{Banded iron formation:}

widespread occurrences, e.g. Isua $\left(2 \times 10^{9}\right.$ tons grading $32 \% \mathrm{Fe}$ );

potential for associated gold (lupin-type).

Layered leucogabbro-anorthosite intrusions:

low-grade chromite resources $(\sim 100$ million tons grading $14 \% \mathrm{Cr}_{2} \mathrm{O}_{3}$ );

potential for platinum group elements (PGE).

Greenstone enclaves:

widespread scheelite occurrences;

potential for volcanic massive sulphides;

potential for gold.

\section{Early Proterozoic supracrustal belts}

Early Proterozoic supracrustal belts with associated infracrustal rocks and intrusions occur in western and eastern Greenland; in the latter region they occur both within and outside the Caledonian fold belt (see section on Palaeozoic orogenic belts below). In this section three mobile belts of western Greenland are discussed: the Rinkian mobile belt, the Inglefield Land mobile belt and the Ketilidian mobile belt. These have an opportunity for a wide range of deposits.

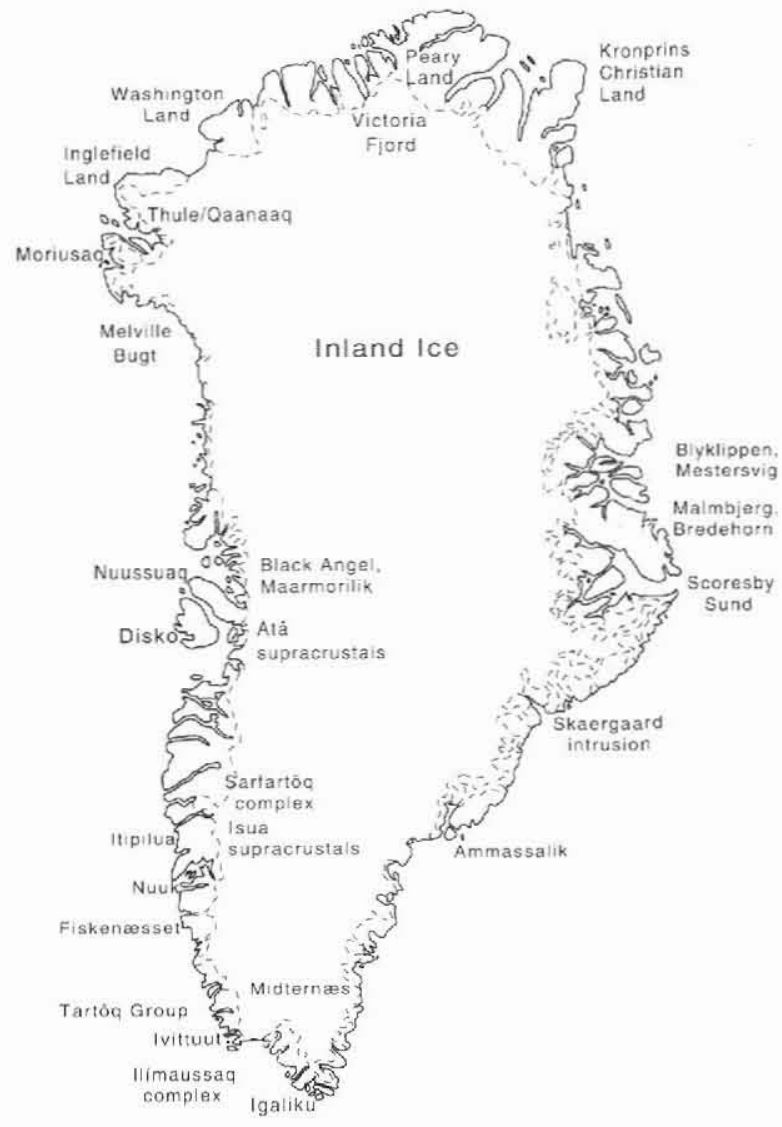

Fig. 2. Map of Greenland showing localities referred to in connection with mineral exploration potential.

The Rinkian mobile belt is a $500 \mathrm{~km}$ wide belt characterised by sedimentation, metamorphism and plutonism and located between $71^{\circ}$ and $75^{\circ} \mathrm{N}$ (Fig. 1). There is general consensus that it represents the eastern extension of the Foxe fold belt of Baffin Island, Canada. Archaean rocks are overlain by a thick Lower Proterozoic epicontinental, predominantly clastic sequence (Karrat Group) which has been folded and variably metamorphosed. The Karrat Group comprises three units: (1) a carbonate unit to the south. (2) a quartzite dominated unit to the north, and overlying these units (3) a thick flysch unit.

The carbonate unit hosted the now exhausted Black Angel mine at Maarmorilik which, during its life of seventeen years, produced 13.6 million tons of ore grading $4.0 \%$ lead, $12.3 \%$ zinc and $29 \mathrm{ppm}$ silver. The main ore bodies, composed of sphalerite, galena and pyrite, are controlled by major folds. Besides the mined occurrences several marble-hosted lead-zinc prospects are known in the general Maarmorilik region and these indicate a potential for Mississippi Valley type deposits. 


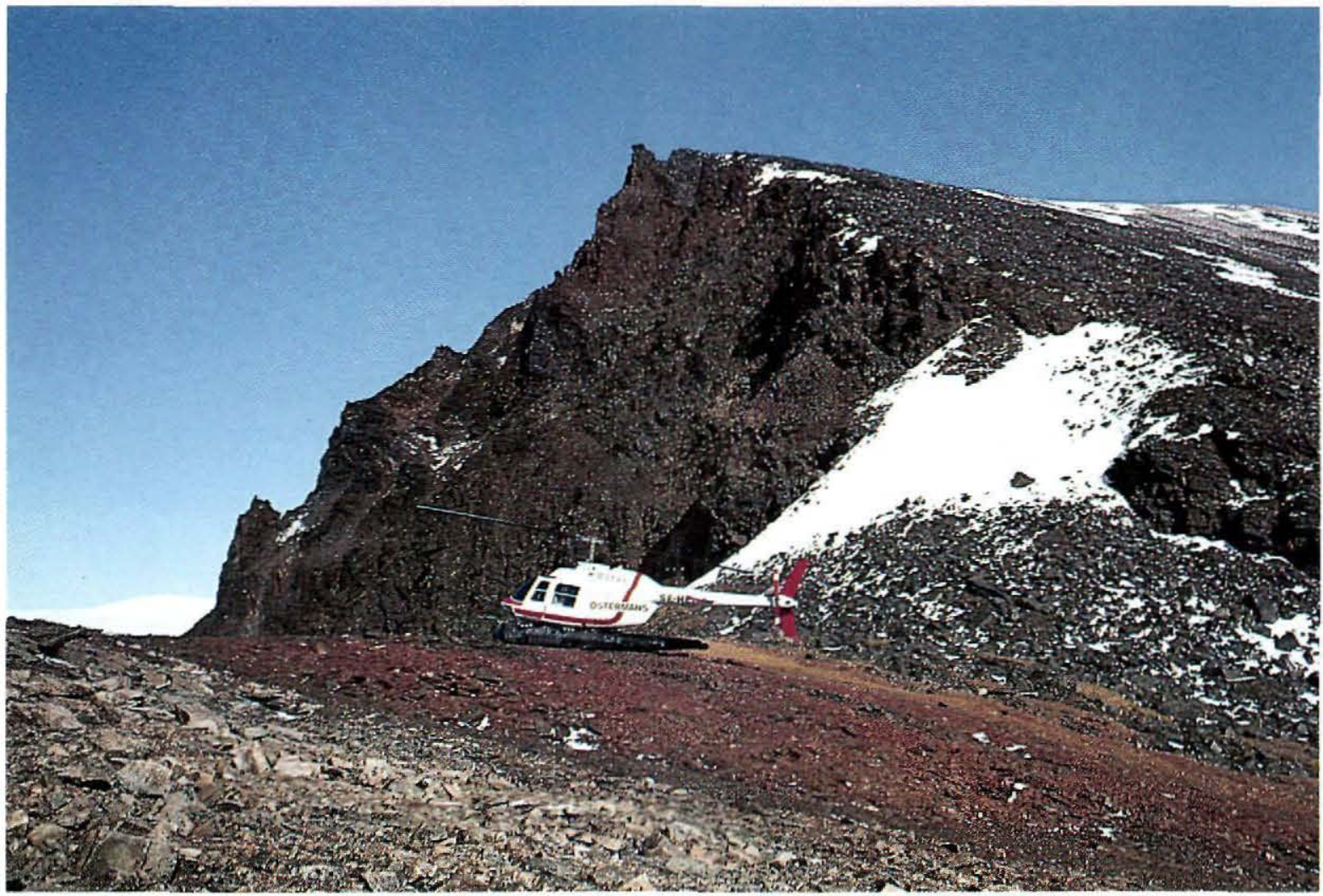

Fig. 3. Banded iron formation with light-coloured psammitic metasediments in the foreground. Melville Bugt, North-West Greenland. Height of section above helicopter about $150 \mathrm{~m}$. Photo: P. R. Dawes.

The younger flysch unit hosts a number of regionally occurring cherty, graphitic iron sulphide horizons. High zinc values have been reported suggesting a potential for sedimentary exhalative-type mineralisation.

\section{Carbonate unit:}

potential for carbonate-hosted lead-zinc, e.g. Black Angel mine (see above).

\section{Flysch unit:}

potential for sedimentary exhalative and shale-hosted gold deposits.

The Inglefield Land mobile belt $\left(78-79^{\circ} \mathrm{N}\right)$ is a direct continuation of the igneous and supracrustal rock complex of adjacent Ellesmere Island (Fig. 1). The supracrustal rocks, several kilometres thick and carbonate rich, now intruded by igneous bodies, show similarities in geological setting and age to the Karrat Group farther south. Gossans, conspicuous features of the landscape in some areas, have regional distribution.

\section{Carbonate and clastic sediments:}

potential for carbonate-hosted lead-zinc and sedimentary exhalative deposits.

The Ketilidian mobile belt occupying the southern tip of Greenland (Fig. 1) is dominated by gneisses, granites and post-tectonic plutons. Supracrustal rocks with mafic volcanics occur along the northern fringe and locally within the belt. The mobile belt shows several significant geochemical gold anomalies.

\section{Greenstones and intrusive complexes:}

several copper prospects;

gold occurrences;

potential for volcanic massive sulphides.

\section{Late Proterozoic intracratonic deposits}

Late Proterozoic activity in Greenland was characterised by rifting and deposition of thick intracratonic sediments associated with igneous activity. Areas in southern, northern and eastern Greenland were affected (see under Palaeozoic orogenic belts for the latter area) but 
only southern Greenland has been the subject of mineral exploration activity. This region hosts the cryolite deposit at Ivittuut, mentioned earlier.

Mineral occurrences encountered in these rift environments point to a variety of exploration targets.

\section{Northern Greenland}

Strata of late Proterozoic (Neohelikian-Hadrynian) age occur in North-West Greenland (Thule Basin) and eastern North Greenland (Peary Land - Kronprins Christian Land). In both regions lower orthoquartzitedominated strata, with basaltic extrusive and intrusive rocks, are overlain by shelf carbonate and siliciclastic deposits. The Thule Basin shows similarities in structural setting and lithology to the coeval deposits on northern Baffin Island, Canada, where carbonatehosted lead-zinc mineralisation is being exploited (Nanisivik mine, see Fig. 1).

Metallic potential is two-fold:

Sedimentary and volcanic rocks:

indications of sedimentary and volcanic hosted copper;

potential for carbonate-hosted lead-zinc.

\section{Southern Greenland}

Faulted outliers of clastic and volcanic rocks (mainly basaltic), intruded by a variety of dykes and central alkaline complexes, characterise the late Proterozoic of southern Greenland and form the Gardar province (Fig. 1). This province is well publicised in the literature; its intrusions, highlighted by the Ilímaussaq complex, constitute one of the classical alkaline provinces of the world. The Gardar province has a high economic mineral potential, including the rare earth elements (REE).

Alkaline and peralkaline intrusions, sedimentary and volcanic rocks:

Ivigtut cryolite deposit (3.7 million tons grading 58\% cryolite);

resource of zirconium, yttrium, beryllium and REE; resource of low grade niobium (30 million tons grading $0.25 \% \mathrm{Nb}$ );

resource of low grade uranium (56 million tons grading $365 \mathrm{ppm} \mathrm{U}$ ).

\section{Palaeozoic orogenic belts}

Palaeozoic fold belts dominate northern and northeastern Greenland. The North Greenland fold belt along the margin of the Arctic Ocean is exposed for 800 $\mathrm{km}$ with a N-S width of up to $200 \mathrm{~km}$; the more extensive East Greenland fold belt outcrops over a strike distance of $1200 \mathrm{~km}$ and is up to $300 \mathrm{~km}$ wide. The two orogenic belts show geological settings and favourable criteria for a range of metallic minerals. The East Greenland belt has seen considerable mineral exploration over several decades; in contrast the northern belt has received little attention from an economic point of view.

The North Greenland fold belt is the eastern part of the Innuitian orogen that stretches through the Arctic Islands of Canada (Fig. 1). It is a product of both mid-Palaeozoic and Cenozoic earth movements that deformed a major Lower Palaeozoic basin. Two lithostructural units dominate. In the south an extensive carbonate platform with major reef occurrences is the direct equivalent of the Palaeozoic reef carbonates of Canada that are known for the carbonate-hosted lead-zinc deposit Polaris (Fig. 1) and a host of other massive sulphide prospects. To the north the deep-water trough dominated by turbidites, now folded and weakly metamorphosed, shows regional zinc anomalies. Both units have economic mineral potential.

\section{Platform carbonates: \\ potential for carbonate-hosted lead-zinc deposits. \\ Trough clastics: \\ potential for sedimentary exhalative deposits.}

The East Greenland fold belt is part of the circumAtlantic Caledonian orogenic system (Fig. 1). The fold belt includes a Late Proterozoic to Ordovician succession of mainly shallow water sediments (Eleonore Bay Supergroup and Lower Palaeozoic carbonates), an extensive metamorphic complex comprising Archaean to Proterozoic rocks reworked during the Caledonian orogeny (gneisses, with supracrustal rocks of possibly four different ages), and late to post-kinematic acid to intermediate intrusions. During the waning stages of the Caledonian orogeny (Devonian - Lower Permian) thick clastic sequences were laid down in intermontane basins.

In East Greenland more than 200 economic mineral occurrences are known. The wealth and variety of mineralisations indicate that the region affected by the $\mathrm{Ca}$ ledonian metallogenetic event is highly attractive.

\section{Shallow water shelf sediments and granitoid intrusions:}

widespread stratabound copper mineralisation; widespread scheelite mineralisation including fault bounded vein type, tungsten-antimony-gold occurrences;

potential for carbonate-hosted lead-zinc and tin deposits associated with granitoid intrusions. 


\section{Late Palaeozoic - Tertiary sediments}

Sediments of Late Palaeozoic to Tertiary age outcrop in eastern North Greenland, extensively in North-East Greenland and in central West Greenland where they are overlain by Tertiary flood basalts (Fig. 1).

In eastern North Greenland (Wandel Sea Basin) the sedimentary succession comprises marine to non-marine, predominantly clastic sediments.

In North-East and central East Greenland between $70^{\circ} \mathrm{N}$ and $78^{\circ} \mathrm{N}$ fault-controlled basins were initiated during Upper Permian times and deposition continued throughout the Mesozoic. The main control of the basins was a series of westerly-tilted fault blocks. The Permian and Triassic section comprises a mixed facies of marine to non-marine sequences; the Jurassic and Cretaceous section is fully marine.

In West Greenland, Lower Cretaceous to Lower Tertiary sediments make up a clastic sequence deposited in fluviatile, deltaic and marine environments.

Only the North-East Greenland occurrences have revealed extensive mineralisations, concentrated in the Upper Permian and Triassic succession (Fig. 2).

Mixed marine and non-marine strata:

numerous baryte occurrences (Bredehorn 300000 tons grading $72 \%$ baryte);

potential for lead-zinc deposits of Irish type;

widespread stratiform and stratabound copper mineralisation of red bed and Kupferschiefer type;

fossil placers ( 5 million tons grading $1-4 \% \mathrm{Zr}$ and 2-13\% Ti).

\section{Late Phanerozoic magmatism}

The late Phanerozoic igneous rocks seen on all sides of Greenland were produced during the important magmatic and tectonic processes that led to the opening of the ocean basins surrounding Greenland.

In North Greenland peralkaline activity affects the outer coast over a distance of $50 \mathrm{~km}$. The effusive rocks with a thickness of $5 \mathrm{~km}$ are tilted towards the south and overthrust by Palaeozoic metasediments. In the central parts of eastern and western Greenland voluminous Tertiary continental basalts occur marking continentalscale magmatism. Composite thicknesses are about 10 $\mathrm{km}$ in the western province, $7 \mathrm{~km}$ in the eastern. In both regions the lavas overlie Cretaceous and early Tertiary sediments of mainly siliclastic origin. In western Greenland a reaction between magma and sediments has occurred leading to eruption of contaminated lava flows bearing native iron and sulphides. This geological scenario resembles that of the Norilsk area of Siberia.
In contrast to western Greenland, plutonic centres are widespread in eastern Greenland where they occur in a $\mathrm{N}-\mathrm{S}$ trending belt more than $1000 \mathrm{~km}$ long. The most renowned of the intrusions is the Skaergaard intrusion $\left(68^{\circ} \mathrm{N}\right)$ where an Au-PGE reef (gold-platinum group elements) is presently the target of active exploration. In the northern part of the province a porphyrymolybdenum deposit occurs at Malmbjerg $\left(72^{\circ} \mathrm{N}\right)$.

Present knowledge of the mineralisations of the Tertiary rocks indicates a multiple metallogenetic event that reveals the tectono-magmatic province of flood basalts, tholeiitic gabbros and felsic alkaline intrusions as an interesting exploration target. Noteworthy mineralisations associated with the Tertiary rocks are:

Layered gabbro, with $A u-P G E$ reefs (43 million tons grading 2.4, ppm Au).

Porphyry molybdenum deposits (150 million tons grading $0.23 \% \mathrm{MoS}_{2}$ ).

Lead-zinc vein type deposits (550 000 tons grading $9 \%$ $\mathrm{Pb}$ and $10 \% \mathrm{Zn}$ ).

Potential for Norilsk type as well as epithermal gold deposits.

\section{Kimberlites and associated rocks}

Kimberlites have as yet only been found in West Greenland where they occur with lamproites and associated rocks piercing Archaean crust to constitute a major province stretching north-south for around $1300 \mathrm{~km}$. Several age groups of intrusions are recognised covering the Proterozoic to Mesozoic. Microdiamonds have been found in kimberlites at both the northern and southern margins of the Archaean craton. Carbonatite complexes occur in the same province. Diamond drilling of one pyrochlore concentration associated with the Sarfartôq carbonatite complex $\left(66^{\circ} \mathrm{N}\right)$ indicates 60000 tons of ore grading $4 \% \mathrm{Nb}_{2} \mathrm{O}_{5}$.

\section{Placer deposits}

A number of surficial deposits have been assessed economically but no commercial extraction has taken place. Apart from the possiblility of alluvial gold occurrences, significant placers in western Greenland are the Moriussaq ilmenite sands $\left(76^{\circ} 30^{\prime} \mathrm{N}\right)$, the Itipilua olivine sand $\left(64^{\circ} \mathrm{N}\right)$ and the Igaliku feldspathic sands $\left(61^{\circ} \mathrm{N}\right)$ (Fig. 2).

\section{Final remarks: assessment of potential}

Greenland holds a central place in the North Atlantic, showing geological connections to North America 
and Europe. However, in contrast to these adjacent regions, Greenland is relatively unexplored from a mineral resource point of view and it can be claimed that the island is the northern hemisphere's last main frontier. The common conception that Greenland is remote and inaccessible is presumably responsible for the low level of exploration activity. The impression of remoteness was perhaps true in the 1950s and 1960s; it is far less true today where an efficient logistic system exists based on sea and air transport. The exploration infrastructure in terms of geological data has also been significantly advanced in the past 30 years and has in turn led to a better understanding of Greenland's geological provinces and to a higher level of metallogenetic interpretation.

The promising mineral potential of Greenland is shown by the exploitation of metallic and industrial minerals already carried out. The cryolite open-pit at Ivittuut and the lead-zinc mines of Blyklippen and Black Angel also drew attention to the feasibility of mining in Greenland's arctic conditions, as well as adaptation to technically difficult local physiography. A number of deposits have been drilled. Those with large mineable reserves have not yet gone into production; low market prices are not balanced by the high starting and transport costs. One example is Malmbjerg, impractically situated between two glaciers in the mountainous terrain of East Greenland (see photograph in Dawes et al., this report) where 150 million tons of molybdenite ore documented decades ago remain unexploited. Seen in relation to the geology of Canada and Europe and to the mining industry of these regions, the odds are that Greenland's promising potential will eventually be realised by new discoveries of economically viable deposits.

H. K. S. \& P. R. D., Geological Survey of Greenland, Copenhagen.

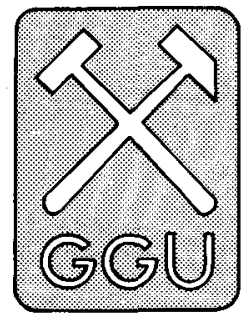

\title{
Greenland MINEX News: a new service for the mining industry
}

\author{
Peter R. Dawes and Henrik Højmark Thomsen
}

In the last few years there has been increased political awareness of the urgency to ensure the continuing and long-term involvement of the mining industry in Greenland's economy. Formalisation of this came in 1990 when an ad hoc working group was convened by the Danish Ministry of Energy and the Chairman of the Greenland Home Rule Authority with the purpose of working out a draft for a new strategy for exploration and utilisation of mineral resources in Greenland. The report containing specific recommendations was released the same year, the text being made available in Danish, English and Greenlandic (MRA, 1990).
In response to these recommendations, the Geological Survey of Greenland (GGU) was involved in a number of activities designed to improve the channelling of geological data from Greenland to international industry. An immediate move was the introduction of a new information service that started with a newsletter directed primarily to the oil industry. The newsletter, called GHEXIS (Greenland Hydrocarbon EXploration Information Service), was distributed for the first time in the fall of 1990 (Pulvertaft, 1991).

On the 'hard mineral' side, the past year saw a number of initiatives to structure information and improve 